\title{
Positive Cell Count
}

National Cancer Institute

\section{Source}

National Cancer Institute. Positive Cell Count. NCI Thesaurus. Code C156548.

A measurement of the number of cells that stain positively in a sample. 